\title{
P68. A new EGFR - EpCAM bispecific antibody enhances the efficacy of adoptive T-cell therapy in a murine gastric tumour model
}

\author{
S Kobold ${ }^{1 *}$, J Steffen ${ }^{1}$, S Grassmann', R Castoldi², J Schmollinger ${ }^{1}$, C Sustmann², G Nierderfellner ${ }^{2}$, C Klein², \\ C Bourquin', S Endres ${ }^{1}$
}

From 1st Immunotherapy of Cancer Conference (ITOC1)

Munich, Germany. 12-14 March 2014

\section{Background}

A limiting step for adoptively transferred tumour-specific $\mathrm{T}$ cells is their recruitment from the blood circulation to the proximity of tumour cells and subsequent engagement in direct tumour cell contact. We hypothesised that a bispecific antibody recruiting $\mathrm{T}$ cells to a target antigen on tumour cells could enhance T-cell-tumour interaction and thus increase the efficacy of adoptively transferred $\mathrm{T}$ cells.

\section{Material and methods}

A new bispecific murine IgG2a antibody (BsAb) was generated that recognises EpCAM as a tumour antigen and truncated EGFR (D-EGFR) as an inert surface marker protein on transduced $\mathrm{T}$ cells. $\mathrm{T}$ cells from transgenic mice for TCR specific for the SV40 large T antigen (TCR-1) were retrovirally transduced with D-EGFR. S.c. tumors were induced in $\mathrm{C} 57 \mathrm{Bl} / 6$ mice by injecting $\mathrm{mGC} 8$ cells derived from a syngeneic large $\mathrm{T}$ antigen expressing EpCAM-positive gastric tumor.

\section{Results}

In vitro, the BsAb increased (4-fold) binding of transduced $\mathrm{T}$ cells to EpCAM positive tumour cells. In the presence of the BsAb, tumour-directed T cells efficiently lysed EpCAM-positive cells (83 \% at a 10:1 effector to target ratio). In vivo, the antibody reached EpCAM+ tumour cells as evidenced by immunofluorescence. mGC8 tumour-bearing mice were treated twice with a combination of the BsAb and transduced TCR-I T cells. Tumour growth was significantly reduced for over

${ }^{1}$ Division of Clinical Pharmacology, Munich, Germany

Full list of author information is available at the end of the article
30 days $(\mathrm{n}=12)$ compared with control groups (transduced T-cells or BsAb alone) and survival was prolonged by $>30$ days $(\mathrm{p}<0.001)$.

\section{Conclusions}

Co-administration of a BsAb bridging adoptively transferred tumour-specific $\mathrm{T}$ cells via an inert surface molecule to a tumour-associated surface antigen enhances the efficacy of therapeutic $\mathrm{T}$ cell transfer.

\section{Authors' details}

${ }^{1}$ Division of Clinical Pharmacology, Munich, Germany. ${ }^{2}$ Roche Diagnostics $\mathrm{GmBH}$, Discovery Oncology, Penzberg, Germany.

Published: 12 March 2014

doi:10.1186/2051-1426-2-S2-P42

Cite this article as: Kobold et al: P68. A new EGFR - EpCAM bispecific antibody enhances the efficacy of adoptive T-cell therapy in a murine gastric tumour model. Journal for ImmunoTherapy of Cancer 2014

2(Suppl 2):P42.

Submit your next manuscript to BioMed Central and take full advantage of:

- Convenient online submission

- Thorough peer review

- No space constraints or color figure charges

- Immediate publication on acceptance

- Inclusion in PubMed, CAS, Scopus and Google Scholar

- Research which is freely available for redistribution 